\title{
Leadership insights of the Chinese military classics: for physician leaders and healthcare administrators
}

\section{Robert W Enzenauer}

Dept of Ophthalmology, UC Health Science Center, Rocky Mountain Lions Eye Institute Aurora, Co, USA
Correspondence: Robert W Enzenauer 9796 East Bayou Hills Lane, Parker, CO 80134 , USA

Tel + I 7207774470

Fax +l 720-777-7348

Email rwenzenauer@pol.net
This article was published in the following Dove Press journal:

Journal of Healthcare Leadership

30 March 2010

Number of times this article has been viewed

\begin{abstract}
Leadership requires an understanding of human nature. Many popular books have been written describing the leadership principles of Biblical figures, athletes, military commanders, and even fictional heroes. Many of the contemporary authors who describe the traits, attributes, and actions that typify successful leaders can find that virtually all of the current leadership philosophy was recognized thousands of years ago. Trite sayings from Chinese military classics often find their way into after-dinner fortune cookies in many American Chinese restaurants. However, the lessons from the Chinese military classics should not be under-estimated and certainly should not be trivialized. Leaders at all levels of healthcare management can learn timeless lessons, spanning three millennia, from the wisdom of ancient
\end{abstract} Chinese military writings.

Keywords: leadership, philosophy

\section{Introduction}

Most contemporary leadership books involve compilations of values, traits, attributes, knowledge base, skill sets, and actions of successful leaders from the military, business, history alike. Loeb and Kindel define leadership as "the set of qualities that causes people to follow." As the authors admit, this definition may be circular, but it does demonstrate that leadership requires at least two parties, a leader and a follower. ${ }^{1}$ The US Army defines leadership as "the process of influencing people by providing purpose, direction, and motivation while operating to accomplish the mission and improving the organization." The definition contains three basic goals: to lead others, to develop the organization and its individual members, and to accomplish the mission. ${ }^{2}$

An enduring expression for Army leadership has been Be-Know-Do. Army leadership begins with what the leader must $\mathbf{B e}$ - the values and attributes that shape character. It is helpful to think of these as internal and defining qualities possessed all the time. As defining qualities, they make up the identity of the leader. The knowledge that leaders should use in leadership is what leaders Know. Knowledge shapes a leader's identity and is reinforced by a leader's actions. While character and knowledge are necessary, by themselves they are not enough. Leaders cannot be effective until they apply what they know. What leaders Do, or leader actions, is directly related to the influence they have on others and what is done. ${ }^{2}$

The Army's Leadership Requirements Model (Table 1) outlines the attributes and competencies that leaders develop to meet these goals. ${ }^{2}$

Rath and Conchie identify three keys to being a more effective leader: knowing your strengths and investing in others' strengths, getting people with the right strengths 
Table I The attributes and competencies of leadership

\begin{tabular}{ll}
\hline Attributes & Core leader competencies \\
\hline What an Army Leader is & What an army leader does \\
A Leader of character & Leads \\
Army values & Leads others \\
Empathy & $\begin{array}{l}\text { Extends influence beyond the } \\
\text { chain of command }\end{array}$ \\
Warrior ethos & Leads by example \\
A Leader with presence & Communicates \\
Military bearing & Develops \\
Physically fit & Creates a positive environment \\
Composed, confident & Prepares self \\
Resilient & Develops others \\
A Leader with intellectual capacity & \\
Mental agility & Achieves \\
Sound judgment & Gets results \\
Innovation & \\
Interpersonal tact & \\
Domain knowledge &
\end{tabular}

on your team, and understanding and meeting the four basic needs of those who look to you for leadership: trust, compassion, stability, and hope. ${ }^{3}$ Bill George felt that authentic leaders demonstrated five qualities: 1) understanding their purpose; 2) practicing solid values; 3) leading with heart; 4) establishing connected relationship; and 5) demonstrating self-discipline. He went on to suggest that for each of the dimensions, a developmental quality is required for leasers to be effective: 1) Purpose: Passion; 2) Values: Behavior; 3) Heart: Compassion; 4) Relationships: Connectedness; and 5) Self-Discipline: Consistency. ${ }^{4}$ Gus Lee captures the essential components of leadership in measureable behaviors, stressing the importance of moral intelligence by modeling and practicing the learnable behaviors of courage. ${ }^{5}$ Greenleaf itemized ten characteristics of successful servantleaders: 1) Listening; 2) Empathy; 3) Healing; 4) Awareness; 5) Persuasion; 6) Conceptualization; 7) Foresight; 8) Stewardship; 9) Commitment to the growth of people; and 10) Building community. ${ }^{6,7}$ In his book Heroic Leadership, Chris Lowney, a former Jesuit, reveals the leadership principles that have guided the Jesuits for more than 450 years: self-awareness, ingenuity, love, and heroism. ${ }^{8}$

Dye and Garman elaborate on what they consider to be the 16 critical competencies for healthcare executives, (Table 1), organizing these 16 leadership competencies into four traits, which they called the cornerstones of exceptional leadership, (Table 2). ${ }^{9}$
In Warrior Politics, Robert D. Kaplan explores the wisdom of the ages for answers for today's leaders. While the modern world may seem more complex and dangerous than ever before, Kaplan writes from a deeper historical perspective to reveal how little things actually change. Drawing on the timeless work of Sun-Tsu, Thucydides, Machiavelli, and Hobbes, among others, Kaplan argues that in a world of unstable states and an uncertain future, it is increasingly imperative to wrest from the past what we need to arm ourselves for the road ahead. ${ }^{10}$ It is from this foundation that I sought to glean leadership insights from the Chinese military classics as had been had done from the Greek historian Xenophon. ${ }^{11}$

\section{Discussion}

Chinese military philosophers have provided the foundation for much of military tactics and strategy. Ever since Sun Tzu's Art of War was translated into English over two hundred years ago, Chinese military thought has furnished, and continues to underlie, many of the fundamental concepts and essential tactics of modern warfare throughout the world. Many current publications simply represent vernacular language translations of the ancient classics. However, other authors have selectively reorganized and reformatted the material to focus upon critical problems and lessons in life. The most popular current versions of the Chinese military classics selectively apply principles and concepts

Table 2 The cornerstones of leadership

\begin{tabular}{ll}
\hline $\begin{array}{l}\text { Cornerstone I: Well-cultivated } \\
\text { self-awareness }\end{array}$ & $\begin{array}{l}\text { Living by personal } \\
\text { conviction } \\
\text { Possessing emotional } \\
\text { intelligence }\end{array}$ \\
Cornerstone 2: Compelling vision & Communicating vision \\
& Earning loyalty and trust \\
Cornerstone 3: Real way with people & Listening like you mean it \\
& Giving feedback \\
& Mentoring others \\
& Developing teams \\
Energizing staff \\
Cornerstone 4: Masterful style of & Generating informal power \\
execution & Building consensus \\
& Making decisions \\
& Driving results \\
Stimulating creativity \\
Cultivating adaptability \\
\hline
\end{tabular}


from Chinese military thought to the world of business. ${ }^{12-28}$ Several authors have transcended the common tendency to conceive of business activities as warfare, to apply these classics in the individual's quest to survive and flourish within corporate culture.

Although Sun Tzu's Art of War is the most famous work on military operations and is the oldest military treatise in the world, Chinese military thought is much more extensive. The seven books preserved in the Seven Military Classics, as traditionally arranged since the Sung dynasty, are Sun Tzu's Art of War, Wu-tzu, Methods of the Ssu-ma (Ssu-ma Fa), Questions and Replies between T'and T'ai-tsung and Li Wei-kung, Wei Liao-tzu, Three Strategies of Huang Shih-kung, and T'ai Kung's Six Secret Teachings. In addition, the recently rediscovered Sun Pin's Military Methods, another Warring States text, essentially constitutes an eighth military classic. Of the Seven Military Classics, only Sun-tzu's Ping-fa, traditionally known as The Art of War, has received much exposure in the West. Ralph Sawyer has recently translated and edited the Chinese Military Classics, discussing all aspects of strategy and tactics in The Art of the Warrior, arranging these writings thematically to give the reader a comprehensive introduction to the Eastern ways of strategy. ${ }^{29}$ According to Sun Tzu, "Warfare is the greatest affair of state, the basis for life... it must be thoroughly pondered and analyzed." ${ }^{\prime 30}$

Effective leadership will continue to be critically important. Physician leaders and healthcare administrators will be forced to deal with increasing challenges, generally "doing more with less" in typical military fashion. I have gleaned examples of what I consider to be attributes, traits, and values of leaders of the Chinese Military Classics from Sawyer's recent publication, reminding our modern healthcare executives and medical leaders of the leadership principles from ancient China that are equally applicable to today.

\section{Leaders are important}

The general is the supporting pillar of state. If his talents are all-encompassing, the state will invariably be strong. If the supporting pillar is marked by fissures, the state will invariably grow weak. ${ }^{31}$ The Art of War.

\section{Leaders provide a vision for the organization}

Li Ching said: "The successful employment of the masses lies in their being of one mind. Unification of the mind lies in prohibiting omens and dispelling doubts. Should the commanding general have anything of which he is doubtful or fearful, emotions will waver." 32 Questions and Replies.

\section{Leaders plan for the future}

If the leader of the army and commander of the masses does not first establish his plans, the proper equipment will not be prepared. ${ }^{33}$ Six Secret Teachings.

If the general doesn't carefully contemplate his course of action his strategists will abandon him. ${ }^{31}$ Huang Shih-kung.

\section{Leaders promote proper values}

When a ruler's actions are cruelly violent, his subordinates will

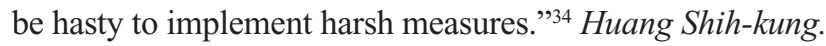

In general, to govern the state and order the army you must instruct them with the forms of propriety, stimulate them with righteousness, and cause them to have a sense of shame. For when men have a sense of shame, in the greatest degree it will be sufficient to wage war, while in the least degree it will suffice to preserve the state. ${ }^{35} \mathrm{Wu}-t z u$.

Now the essence of employing the army lies in respecting the forms of propriety and making salaries generous. When the proper forms of propriety are followed, wise officers will be attracted. When salaries are generous righteous officers will regard death lightly. Thus if when granting salaries to the "worthy" you do not begrudge the expense, and when rewarding the "able" are not dilatory, then the strength of your subordinates will be united, while your enemy's state will be reduced as the "capable" abandon him.

The Way to employ men is to honor them with rank and supply them generously with material goods, for then the officers will come of their own accord. Welcome them according to the forms of propriety, stimulate them with righteousness, and then the officers will die for the state. ${ }^{35}$ Huang Shih-kung.

\section{Leaders take responsibility}

If you failed to direct them to victory accept the blame yourself. ${ }^{35} \mathrm{Ssu}-\mathrm{ma} \mathrm{Fa}$.

\section{Leaders show initiative}

Thus the highest realization of warfare is to attack the enemy's plans; next, is to attack their alliances; then to attack their army; and the lowest is to attack their fortified cities. ${ }^{36}$ The Art of War.

If the enemy opens the door, you must race in. Attack what they love first. Do not fix any time for battle, assess and react to the enemy in order to determine the strategy for battle." ${ }^{36}$ The Art of War.

\section{Leaders are creative}

It is the nature of the army to stress speed; to take advantage of the enemy's absence; to travel unanticipated roads; and to attack when they are not alert. ${ }^{36}$ The Art of War. 


\section{Leaders know when to react}

If it is not advantageous, do not move. If objectives cannot be attained, do not employ the army. Unless endangered do not engage in warfare. ${ }^{30}$ The Art of War.

Mount a sudden strike on their doubts. Attack their haste. Force them to constrict their deployment. Launch a sudden strike against their order. Take advantage of their failure to avoid harm. Obstruct their strategy. Seize their thoughts. Capitalize on their fears. ${ }^{37}$ Ssu-ma Fa.

In general, whoever occupies the battleground first and awaits the enemy will be at ease; whoever occupies the battleground afterward and must race to the conflict will be fatigued. Thus one who excels at warfare compels men and is not compelled by other men. ${ }^{38}$ The Art of War.

\section{Leaders have insight}

Thus it is said that one who knows the enemy and knows himself will not be endangered in a hundred engagements. One who does not know the enemy but knows himself will sometimes be victorious, sometimes meet with defeat. One who knows neither the enemy nor himself will invariably be defeated in every engagement. ${ }^{36}$ The Art of War.

King Wu asked the T'ai Kung: "Before engaging in battle I want to first know the enemy's strengths and weaknesses, to foresee indications of victory or defeat. How can this be done?" The T'ai Kung replied, "Indications of victory or defeat will be first manifest in their spirit. The enlightened general will investigate them, for they will be evidenced in the men." ${ }^{39}$ Six Secret Teachings.

\section{Leaders are consistent}

If orders are consistently implemented to instruct the people, then the people will submit. If orders are not consistently implemented to instruct the people, then the people will not submit. One whose orders are consistently carried out has established a mutual relationship with the people. ${ }^{40}$ The Art of War.

"If the laws and orders are not clear, rewards and punishments not trusted - when sounding the gongs will not cause them to halt, nor beating the drum to advance - then even if you had a million men, of what use would they be?"40 Wu-tzu.

\section{Leaders provide clear expectations of performance}

If his instructions are not precise and trusted, the officers and men will not be trained." ${ }^{33}$ Six Secret Teachings.

\section{Leaders are sincere}

King Wei said: "How can we cause the people to always listen to orders?" Sun Pin replied: "Always be sincere."40 Military Methods.

If the general can think of his officers as if thirsty, his plans will be followed. ${ }^{31}$ Huang Shih-kung.

\section{Leaders are honest, trustworthy and fair}

Accordingly, when righteousness overcomes desire one will flourish; when desire overcomes righteousness one will perish." ${ }^{34}$ Six Secret Teachings.

In general, with regard to the people; rescue them with benevolence; engage in battle with righteousness; make decisions through wisdom; fight with courage; exercise sole authority through credibility; encourage them with profits; and gain victory through achievements. Thus the mind must embody benevolence and actions should incorporate righteousness. ${ }^{36}$ Ssu-ma Fa.

The general cannot be without credibility. If he is not trusted then his orders will not be implemented. If his orders are not implemented, then the army will not be unified. If the army is not unified then it will not attain fame. The credibility is the feet of the army. ${ }^{31}$ Military Methods.

Only benevolence can attract people; however, if one is benevolent but not trustworthy, then on the contrary he will vanquish himself. Treat men as men, be upright with the upright, employ appropriate language, and use fire only where it should be used. ${ }^{40}$ Ssu-ma Fa.

The Military Pronouncements states: "The exemplary general, in his command of the army, governs men as he would want to be treated himself. Spreading his kindness and extending his beneficence, the strength of his officers is daily renewed. In battle they are like the wind arising, their attack is like the release of a pent-up river." ${ }^{\prime 40}$ Huang Shih-kung.

The general cannot but be righteous. If he is not righteous then he will not be severe. If he is not severe then he will not be awesome. If he is not awesome then the troops will not die for him. Thus righteousness is the head of the army.

The general cannot but be benevolent. If he is not benevolent then the army will not conquer. If the army does not conquer it will lack achievement. Thus benevolence is the belly of the army.

The general cannot be without Virtue. If he lacks Virtue then he will not have any strength. If he lacks strength the advantages of the Three Armies will not be realized. Thus Virtue is the hands of the army..$^{31}$ Military Methods.

If he transfers his anger to the innocent the whole army will be afraid. ${ }^{31}$ Huang Shih-kung. 


\section{Leaders provide timely reward and punishment}

When the bestowing of rewards does not extend past the day; the imposition of punishments is as quick as turning the face; and they are not affected by the man nor subject to external threats, this is the general of the army's Virtue. ${ }^{41}$ Military Methods.

In general, in employing rewards, one values credibility; in employing punishments one values certainty. When rewards are trusted and punishments inevitable wherever the eye sees and the ear hears, then even where they do not see or hear there is no one who will not be transformed in their secrecy. Since the ruler's sincerity extends to Heaven and Earth, and penetrates to the spirits, how much the more so to men? ${ }^{41}$ Six Secret Teachings.

Victory in war lies in establishing awesomeness. Establishing awesomeness lies in uniting strength. Uniting strength lies in rectifying punishments. By rectifying punishments rewards are illuminated. ${ }^{41}$ Wei Liao-tsu.

Rewards should not be delayed beyond the appropriate time, for you want the people to quickly profit from doing good. When you punish someone do not change his position, for you want the people to quickly see the harm of doing what is not good. ${ }^{41} \mathrm{Ssu}-\mathrm{ma} \mathrm{Fa}$.

If good and evil are treated alike the meritorious officers will grow weary. ${ }^{31}$ Huang Shih-kung.

The general creates awesomeness by executing the great, and becomes enlightened by rewarding the small. Prohibitions are made effective and laws implemented by careful scrutiny in the use of punishments. Therefore if by executing one man the entire army will quake, kill him. If by rewarding one man the masses will be pleased, reward him. In executing, value the great; in rewarding, value the small. When you kill the powerful and the honored, this is punishment that reaches the pinnacle. When rewards extend down to the cowherds, grooms, and stablemen, these are rewards penetrating downward to the lowest. When punishments reach the pinnacle, and rewards penetrate to the lowest, then your awesomeness has been effected. ${ }^{41} \mathrm{Six}$ Secret Teachings.

T'ien Chi said: "Are not rewards and punishments the most urgent matters for the military?"

Sun Pin replied "They are not. No rewards are the means by which to give happiness to the masses and cause soldiers to forget death. Punishments are the means by which to rectify the chaotic and cause the people to fear their superiors. They can be employed to facilitate victory, but they are not urgent matters." ${ }^{" 41}$ Military Methods.

\section{Leaders uphold the highest standards of ethical behavior}

The T'ai Kung said "If the ruler lacks moral worth, then the state will be in danger and the people in turbulence. If the ruler is a Worthy or Sage, then the state will be at peace and the people well ordered." ${ }^{42}$ Six Secret Teachings.

If he is greedy, treachery will be unchecked. If he is preoccupied with women then the officers and troops will become licentious. ${ }^{31}$ Huang Shih-kung.

\section{Leaders select good subordinates and associates}

If the general relies solely upon himself his subordinates will shirk all responsibility. ${ }^{31}$ Huang Shih-kung.

King Wen asked the T'ai Kung "How does the ruler of the state and leader of the people come to lose his position?"

The T'ai Kung replied: "He is not cautious about whom he has as associates." ${ }^{33}$ Six Secret Teaching.

When Worthy ministers are brought inside the government depraved ones will be outside. When depraved ministers are inside worthy ministers will perish. When within and without lose what is appropriate, disaster and disorder will last through generations. ${ }^{43}$ Huanh Shih-kung.

\section{Leaders have loyal followers}

Now one who is not loved and cherished in the minds of his men cannot be employed by me; one who is not respected and feared in the minds of his men cannot be appointed by me. Love follows from below, awesomeness is established from above. If they love their general they will not have divided minds; if they are awestruck by their general they will not be rebellious. Thus excelling at generalship is merely a question of love and awesomeness. ${ }^{40} \mathrm{Wei}$ Liao$t z u$.

When the general regards his troops as young children, they will advance into the deepest valleys with him. When he regards the troops as his beloved children, they will be willing to die with him. ${ }^{21}$ The Art of War.

\section{Leaders inspire their followers}

Now what I term governing well means causing the people not to have any selfish interests. If the people do not have selfish interests then all under Heaven will be one family. ${ }^{44}$ Wei Liao-tzu.

In general, on the battlefield, soon to become a graveyard, if the soldiers are committed to fight to the death they will live, whereas if they seek to stay alive they will die. ${ }^{32} W u-t z u$. 
If you treat them deferentially, then the officers will die for you; the officers will die, but their names will be transmitted. If you encourage them with fundamental pleasures, they will die for their native places. If you importune them with family relationships, they will die for the ancestral graves. If you honor them with feasts, they will die for food and drink. If you have them dwell in tranquility, they will die in the urgency of defense. If you inquire about their febrile diseases, they will die for your solicitude. ${ }^{35}$ Military Methods.

If one can cause his men themselves to want to fight, then no one will be able to oppose their ardor. ${ }^{45}$ Questions and Replies The general creates awesomeness by executing the great. ${ }^{41}$ Six Secret Teachings.

\section{Leaders reward superior performance}

The Way to employ men is to honor them with rank and supply them generously with material goods, for then the officers will come of their own accord. Welcome them according to the forms of propriety, stimulate them with righteousness, and then the officers will die for the state. ${ }^{35}$ Huang Shih-kung.

When the ruler regards the good as good but doesn't advance them, while he hates the evil but doesn't dismiss them; when the worthy are hidden and covered, while the unworthy hold positions, then the state will suffer harm." ${ }^{34}$ Huang Shih-kung.

In general, if in warfare you are victorious, share the achievement and praise with the troops. ${ }^{35} \mathrm{Ssu}-\mathrm{ma} \mathrm{Fa}$.

The commander-in-chief's method focuses upon winning the minds of the valiant; rewarding and providing salaries to the meritorious; and having his will penetrate to the masses. ${ }^{40}$ Huang Shih-kung.

The hegemons governed their officers by virtue of authority, bonding them through trust, motivating them with rewards. When that trust declined the officers grew distant, and when rewards became inadequate they would not submit to orders. ${ }^{46}$ Huang Shih-kung.

Now the essence of employing the army lies in respecting the forms of propriety and making salaries generous. When the proper forms of propriety are followed, wise officers will be attracted. When salaries are generous righteous officers will regard death lightly. Thus if when granting salaries to the Worthy you do not begrudge the expense, and when rewarding the able are not dilatory, then the strength of your subordinates will be united, while your enemy's state will be reduced as the capable abandon him. ${ }^{35}$ Huang Shih-kung.

\section{Leaders take care of their followers}

King Wen said to the T'ai Kung: "I would like to learn about the affairs of administering the state. If I want to have the ruler honored and the people settled, how should I proceed?" T'ai Kung replied: "Just love the people."

King Wen: "How does one love the people?"

T'ai Kung replied: "Profit them, do not harm them. Help them to succeed, not defeat them. Give them life, do not slay them. Grant, do not take away. Give them pleasure, do not cause them to suffer. Make them happy, do not cause them to be angry. ${ }^{{ }^{47}}$ Six Secret Teachings.

In general, with regard to the people: rescue them with benevolence. ${ }^{36}$ Ssu-ma Fa.

When bestowing your beneficence upon the people you cannot begrudge the expense. The people are like cows and horses. Frequently make gifts of food and clothing, and follow up by loving them. ${ }^{42}$ Six Secret Teachings.

In order to stimulate the soldiers, the people's material welfare cannot but be ample. The ranks of nobility, the degree of relationship in death and mourning, the activities by which the people live, cannot but be made evident. One must govern the people in accord with their means to life, and make distinctions clear in accord with the people's activities. The fruits of the field and their salaries, the feasting of relatives through the rites of eating and drinking, the mutual encouragement in the village ceremonies, mutual assistance in death and the rites of mourning, sending off and greeting the troops - these are what stimulate the people. ${ }^{35}$ Wei Liao-tzu.

\section{Leaders set the example and lead from the front}

If you lead the men in person your soldiers will become the most valiant under heaven. ${ }^{40}$ Huang Shih-kung.

When Wu Ch'I engaged Sh'in in battle, wherever he encamped the army did not flatten the paths between the fields. Young saplings provided protective covering against the frost and dew. Why did he act like this; because he didn't place himself higher than other men. If you want men to die you don't require them to perform perfunctory acts of respect. If you want men to exhaust their strength you don't hold them responsible for performing the rites. Thus in antiquity an officer wearing a helmet and armor didn't bow, showing people that he is not troubled by anything. To annoy people yet require them to die, to exhaust their strength, from antiquity until today has never been heard of. ${ }^{31}$ Wei Liao-tzu.

Now those who command the army must share tastes and attitudes with the officers and men, and confront both safety 
and danger with them, for then the enemy can be attacked. Thus the army will attain full victory, and the enemy will be completely destroyed.

$\mathrm{He}$ is with them in safety; he is united with them in danger. Thus his troops can be combined but cannot be forced apart. They can be employed but cannot be tired out. With his beneficence he ceaselessly gathers them together, with his plans he constantly unites them. Thus it is said that when you cultivate beneficence tirelessly, with one you can take ten thousand. ${ }^{31}$ Huang Shih-kung.

Now when the army is toiling on the march the general must establish himself as an example. In the heat he does not set up an umbrella; in the cold he doesn't wear heavier clothes. On difficult terrain he must dismount and walk. Only after the army's well is finished does he drink. Only after the army's food is cooked does he eat. Only after the army's ramparts are complete does he rest. He must personally experience the same toil and respite. In this fashion even through the army is in the field for a long time, it will be neither old nor exhausted. ${ }^{31} \mathrm{Wei}$ Liao-tzu.

If you must fight again, swear an oath and assume a forward position. ${ }^{35} \mathrm{Ssu}$-ma Fa.

If the general isn't courageous the officers and troops will be terrified. ${ }^{31}$ Huang Shih-kung.

If you are respectful the troops will be satisfied. If you lead in person they will follow. When orders are annoying they will be ignored. When Commands are issued in proper measure they will be seriously regarded. When the drumbeat is rapid they will move quickly; when the drumbeat is more measured they will move accordingly. When their uniforms are light they will feel quick; if lustrous they will feel stalwart. ${ }^{40}$ Ssu-ma Fa.

The Military Pronouncements states: "When the army's wells have not yet been completed the general does not mention thirst. When the encampment has not yet been secured the general does not speak about fatigue. When the army's cook stoves have not yet been lit the general does not speak about hunger. In the winter he doesn't wear a fur robe; in the summer he doesn't use a fan; and in the rain he doesn't set up an umbrella." This is termed the proper form of behavior for a general. ${ }^{31}$ Huang Shih-kung.

Thus those who engage in combat must take leading in person as their foundation in order to incite the masses and officers, just as the mind controls the four limbs. If their minds are not incited, then the officers will not die for honor. When the officers will not die for honor, then the masses will not do battle. ${ }^{40}$ Wei Liao-tzu.
In antiquity, when outstanding generals commanded armies, there was once a case where the commander was presented with a cask of sweet wine. The general had it poured into the river and shared the drinking of the wine with the officers and men as it flowed downstream. Now a cask of wine is unable to flavor a river of water, but the officers of the Three Armies were all motivated to fight to the death because the flavor and taste reached them personally. ${ }^{31}$ Huang Shih-kung.

"The general shares heat and cold, labor and suffering, hunger and satiety with the officers and men. Therefore when the masses of the Three Armies hear the sound of the drum they are happy, and then they hear the sound of the gong they are angry. When attacking a high wall or crossing a deep lake under a hail of arrows and stones, the officers will compete to be first to scale the wall. When the naked blades clash the officers will compete to be the first to go forward. It's not because they like death and take pleasure in being wounded, but because the general knows their feelings of heat and cold, hunger and satiety, and clearly displays his knowledge of their labor and suffering." ${ }^{35}$ Six Secret Teachings.

\section{Conclusion}

Many leadership issues are the same regardless of industry, but healthcare presents many unique challenges. But as Dye and Garman point out, "the life-and-death nature of the work, emotional demands, and financial challenges in this industry are very different from those in other fields. Because of these unique qualities, the healthcare field requires its leaders to have a distinctive approach as well." Dye and Garmin contend "the greatest challenge of the next decade in healthcare could very well be the development of leaders equipped to deal with the healthcare field, which is facing declining reimbursement, a complex tapestry of professional labor shortages, and the increasing sophistication and costs of medical technology." 9

Thomas E. Beeman believes that leadership development is important because of: the crisis that America finds itself in; because of the ethical vacuum that has been created by a lack of organizational leadership in American business combined with a dearth in personal values and accountability. "In healthcare, which is ever more a public trust, the need for transformational and ethical leaders is a paramount concern. Much of our healthcare crises have been caused by a focus on the economics and commoditization of healthcare rather than on the ethics and rights of healthcare." Beeman feels that the focus on developing character, which is and must be the fundamental element of leadership. ${ }^{9}$ 


\section{Disclosures}

The authors disclose no conflicts of interest.

The ability to lead others is a learned skill. And like any learned skill, its traits and tenets can be acquired through study and honed through practice before they are tested in the field. ${ }^{48}$ Dye and Garman believe that exceptional leadership can be learned by those who are not natural-born leaders and that the practices, also known as competencies of exceptional leaders can be picked up by anyone. ${ }^{9}$ However, it is clear that virtually all of the traits, attributes, values, and now the critical competencies of successful leaders in general, and healthcare executives in particular, can be recognized in the writings of the Chinese military classics (written from 500 $\mathrm{BCE}$ to $700 \mathrm{CE})$.

\section{Suggested reading list}

1. Sawyer RD. The Art of the Warrior: Leadership and Strategy from the Chinese Military Classics. Boston, MA: Shambhala Publications, Inc; 1996.

2. Enzenauer RW. Leadership Insights of Xenophon. The Physician Executive. 2004;30(4):34-37.

3. Cleary T. Zen Lessons: The art of leadership. Boston, MA: Shambhala Publications, Inc; 2007.

4. Cleary T. The book of leadership and strategy: Lessons of the Chinese Masters. Boston, MA: Shambhala Publications, Inc; 1990.

5. Cleary T. Ways of warriors, Codes of kings. Lessons in leadership from the Chinese Classics. Boston, MA: Shambhala Publications, Inc; 2000.

6. Sawyer RD. The Essence of War: Leadership and Strategy from the Chinese Military Classics. Boulder, CO: Westview Press; 2004.

\section{References}

1. Loeb M, Kindel S. Leadership for Dummies. New York, NY: Wiley Publishing, Inc; 1999.

2. Department of the Army. Army Leadership, FM 6-22. Washington, DC; US Government Printing Office; 2006.

3. Rath T, Conchie B. Strengths based leadership: Great leaders, teams, and why people follow. New York, NY: Gallup Press; 2008.

4. George B. Authentic Leadership: Rediscovering the Secrets to Creating Lasting Value. San Francisco, CA: Jossey-Bass; 2003.

5. Lee G, Elliott-Lee D. Courage - the backbone of leadership. San Francisco, CA: Jossey-Bass; 2006.

6. Greenleaf RK. Servant Leadership: A Journey into the Nature of Legitimate Power and Greatness. Mahwah, NJ: Paulist Press; 1977.

7. Greenleaf RK, Beazley H, Beggs J, Spears LC, eds. The Servant Leader within: A transformative path. Mahwah, NJ: Paulist Press; 2003.

8. Lowney C. Heroic Leadership: Best Practices from a 450-Year-Old Company That Changed the World. Chicago, IL: Loyola Press, Chicago; 2005.

9. Dye CF, Garman AN. Exceptional Leadership: 16 critical competencies for healthcare executives. Chicago, IL: Health Administration Press; 2006.
10. Kaplan RD. Warrior Politics: Why leadership demands a pagan ethos. New York, NY: First Vintage Books; 2003.

11. Enzenauer RW. Leadership Insights of Xenophon. The Physician Executive. 2004;30(4):34-37.

12. Bing S. SunTzu Was a Sissy: How to Conquer Your Enemies, Promote Your Friends, and Wage the Real Art of War. New York, NY: Harper Business; 2004.

13. Brahm LJ. Doing Business in China: Sun Tzu's the Art of War As a Means of Understanding How the Chinese Do Business. Boston, MA: Tuttle Publishing; 2004.

14. Chan MWL. Sunzi's Art of War and Management Strategy. Bloomington, IN: iUniverse.com; 1998.

15. Chen B, Chan MWL. Sunzi on the Art of War and its General Application to Business. Bloomington, IN: iUniverse.com; 1998.

16. Chu C-N. Working Woman's Art of War: Winning Without Confrontation. Clearwater, FL: AMC Publishing; 2001.

17. Gagliardi G. Sun Tzu's The Art of War Plus the Art of Management. Seattle, WA: Clearbridge Publishing; 2000.

18. Gagliardi G. Sun Tzu's The Art of War Plus the Art of Marketing. Seattle, WA: Clearbridge Publishing; 2000.

19. Giles L. Sum Tzu on the Art of War-A Business Strategy Handbook. Austin, TX: Hale Fred Press; 1991.

20. Khoo K-H. Sun Tzu's Business and Management Series: Applying Sun Tzu's Art of War in Customer Service, Corporate Planning, Human Resource Management, Marketing, Selling and Winning. Philadelphia, PA: Coronet Books, Inc; 2002.

21. Krause DG. The Way of the Leader: Applying the Principles of Sun Tzu and Confucius, Ancient Strategies for the Modern Business World. New York, NY: Perigee Books, Berkley Publishing Co; 1997.

22. Krause DG. The Art of War for Executives. New York, NY: Perigee Books, Berkley Publishing Co; 1995.

23. Lundell D. Sun Tzu's The Art of War for Traders and Investors. New York, NY: McGraw-Hill Trade; 1997.

24. Michaelson GA, Michaelson SW. Sun Tzu for Success: How to Use the Art of War to Master Challenges and Accomplish the Important Goals in Your Life. Avon, MA: Adams Media Corporation; 2003.

25. Michaelson GA, Michaelson SW. Sun Tzu's Strategies for Selling: How to Use the Art of War to Build Lifelong Customer Relationships. New York, NY: McGraw-Hill; 2003.

26. Michaelson GA. Sun Tzu: The Art of War for Managers; 50 Strategic Rules. Avon, MA: Adams Media Corporation; 2001.

27. Teck FC, Grinyer PH. Suntzu on Management: The Art of War in Contemporary Business Strategy. Oxford, England: Butterworth-Heinemann; 1996.

28. Wu R, Wang J, Wu J-S. Sun Zi's Art of War and Health Care: Military Science and Medical Science. Beijing, China: New World Press; 1997.

29. Sawyer RD (translator and editor). The Art of the Warrior: Leadership and Strategy from the Chinese Military Classics. Boston, MA: Shambhala Publications, Inc; 1996.

30. Sawyer RD. Chapter 1. The Nature of Warfare. In: Sawyer RD. The Art of the Warrior: Leadership and Strategy from the Chinese Military Classics. Boston, MA: Shambhala Publications, Inc; 1996. p. 73-78.

31. Sawyer RD. Chapter 15. Generals and Generalship. In: Sawyer RD. The Art of the Warrior: Leadership and Strategy from the Chinese Military Classics. Boston, MA: Shambhala Publications, Inc; 1996. p. $150-161$.

32. Sawyer RD. Chapter 8. Doubt and Timeliness. In: Sawyer RD. The Art of the Warrior: Leadership and Strategy from the Chinese Military Classics. Boston, MA: Shambhala Publications, Inc; 1996. p. 114-117.

33. Sawyer RD. Chapter 4. Tactical and Strategic Planning. In: Sawyer RD. The Art of the Warrior: Leadership and Strategy from the Chinese Military Classics. Boston, MA: Shambhala Publications, Inc; 1996. p. 88-90.

34. Sawyer RD. Chapter 2. The Tao of Rulership. In: Sawyer RD. The Art of the Warrior: Leadership and Strategy from the Chinese Military Classics. Boston, MA: Shambhala Publications, Inc; 1996. p. $79-82$. 
35. Sawyer RD. Chapter 19. Motivating Warriors. In: Sawyer RD. The Art of the Warrior: Leadership and Strategy from the Chinese Military Classics. Boston, MA: Shambhala Publications, Inc; 1996. p. 170-174.

36. Sawyer RD. Chapter 7. The Tao of Warfare. In: Sawyer RD. The Art of the Warrior: Leadership and Strategy from the Chinese Military Classics. Boston, MA: Shambhala Publications, Inc; 1996. p. 101-113.

37. Sawyer RD. Chapter 29. Fundamental Tactical Principles. In: Sawyer RD. The Art of the Warrior: Leadership and Strategy from the Chinese Military Classics. Boston, MA: Shambhala Publications, Inc; 1996. p. 221-224.

38. Sawyer RD. Chapter 27. Manipulating the Enemy. In: Sawyer RD. The Art of the Warrior: Leadership and Strategy from the Chinese Military Classics. Boston, MA: Shambhala Publications, Inc; 1996. p. 214-218.

39. Sawyer RD. Chapter 30. Evaluating the Enemy. In: Sawyer RD. The Art of the Warrior: Leadership and Strategy from the Chinese Military Classics. Boston, MA: Shambhala Publications, Inc; 1996. p. 225-230.

40. Sawyer RD. Chapter 13. Command and Control. In: Sawyer RD. The Art of the Warrior: Leadership and Strategy from the Chinese Military Classics. Boston, MA: Shambhala Publications, Inc; 1996. p. 136-147.

41. Sawyer RD. Chapter 21. Rewards and Punishments. In: Sawyer RD. The Art of the Warrior: Leadership and Strategy from the Chinese Military Classics. Boston, MA: Shambhala Publications, Inc; 1996 p. 181-187.
42. Sawyer RD. Chapter 11. Rulership. In: Sawyer RD. The Art of the Warrior: Leadership and Strategy from the Chinese Military Classics. Boston, MA: Shambhala Publications, Inc; 1996. p. 129-133.

43. Sawyer RD. Chapter 12. Power and Authority. In: Sawyer RD. The Art of the Warrior: Leadership and Strategy from the Chinese Military Classics. Boston, MA: Shambhala Publications, Inc; 1996. p. 134-135.

44. Sawyer RD. Chapter 5. Preparations. In: Sawyer RD. The Art of the Warrior: Leadership and Strategy from the Chinese Military Classics. Boston, MA: Shambhala Publications, Inc; 1996. p. 91-93.

45. Sawyer RD. Chapter 20. Psychology of Warfare. In: Sawyer RD. The Art of the Warrior: Leadership and Strategy from the Chinese Military Classics. Boston, MA: Shambhala Publications, Inc; 1996. p. 175-180.

46. Sawyer RD. Chapter 6. The History of Warfare. In: Sawyer RD. The Art of the Warrior: Leadership and Strategy from the Chinese Military Classics. Boston, MA: Shambhala Publications, Inc; 1996. p. 94-100.

47. Sawyer RD. Chapter 3. The People. In: Sawyer RD. The Art of the Warrior: Leadership and Strategy from the Chinese Military Classics. Boston, MA: Shambhala Publications, Inc; 1996. p. 83-87.

48. Johnson WB, Gregory P. Harper GP. Becoming a Leader the Annapolis Way: 12 Combat Lessons from the Navy's Leadership Laboratory. New York, NY: McGraw-Hill Books; 2005.
Journal of Healthcare Leadership

\section{Publish your work in this journal}

The Journal of Healthcare Leadership is an international, peer-reviewed, open access journal focusing on leadership for the health profession. The journal is committed to the rapid publication of research focusing on but not limited to: Healthcare policy and law; Theoretical and practical aspects healthcare delivery; Interactions between healthcare and society and evidence-based practices;

\section{Dovepress}

Interdisciplinary decision-making; Philosophical and ethical issues; Hazard management; Research and opinion for health leadership; Leadership assessment. The manuscript management system is completely online and includes a very quick and fair peer-review system. Visit http://www.dovepress.com/ testimonials.php to read real quotes from published authors. 